\title{
Physicochemical and microbiological changes of bovine blood due to high hydrostatic pressure treatment
}

\author{
B. Csehi* (D), B. Salamon, T. Csurka, E. Szerdahelyi, L. Friedrich and \\ K. Pásztor-Huszár
}

Institute of Food Science and Technology, Hungarian University of Agriculture and Life Sciences, Villányi str. 29-43., H-1118 Budapest, Hungary

\section{ORIGINAL RESEARCH PAPER}

Received: December 8, 2020 • Accepted: April 29, 2021

Published online: June 24, 2021

(C) 2021 The Author(s)

\begin{abstract}
Bovine blood samples were treated with high hydrostatic pressure (HHP) to examine the changes that may occur in the blood related to its colour, microbiological characteristics, protein denaturation, and dynamic viscosity. Pressure treatments were carried out from 100 to $600 \mathrm{MPa}$ in $100 \mathrm{MPa}$ scale up, with 5 min holding time. The blood samples were treated with anticoagulant (EDTA) to eliminate the possible measurement distorting effects. We found that $2 \mathrm{log}$ reduction in the microbial load could be achieved with a pressure treatment above $400 \mathrm{MPa}$. According to the protein denaturation measurements (DSC), blood proteins were resistant to pressure treatment, even at 300-400 MPa a substantial part of proteins remained in native state. The colour of the samples got darker with the rising pressure, however, visible colour change was observed only above $400 \mathrm{MPa}$. It can be established, that the HHP treatment was suitable to increase the microbiological stability of blood, without significantly changing its techno-functional properties.
\end{abstract}

\section{KEYWORDS}

bovine blood, microbiological stability, high hydrostatic pressure, colour, DSC

*Corresponding author. Tel.: +36 1 3057660. E-mail: Csehi.Barbara@uni-mate.hu 


\section{INTRODUCTION}

Blood is a specific connective tissue in liquid state, built up from plasma with suspended elements in it, a rich source of iron and protein (Ofori and Hsieh, 2011). Blood as a resource is currently scarcely used, despite the fact that the protein content of whole blood is approx. $18 \%$, the protein content of the plasma is 6-8 $\mathrm{g} \mathrm{dL}^{-1}$ in pigs and 7-9 $\mathrm{g} \mathrm{dL}^{-1}$ in cattle (In et al., 2002; Lynch et al., 2017). Apart from it being a protein source, knowing the proportion of anaemia caused by iron deficiency in the population - primarily among youngsters and women - the other most important nutrient in blood is iron. Pig blood contains $1,490.14 \mathrm{mg} \mathrm{kg}^{-1}$ of iron in terms of dry matter content, which is outstanding among food products (Sorapukdee and Narunatsopanon, 2017).

Last year's estimated "waste" of this rich protein source only from pigs was 6,465 tonnes in Hungary, 625,352 tonnes in Europe, and 435,524 tonnes in the USA according to Eurostat and USDA slaughter statistics from 2018 (Eurostat, 2020; USDA, 2020). It is estimated that China produces $1,500,000$ tonnes of pig blood per year with a protein content equivalent to 2,000,000 tonnes of meat or 2,500,000 eggs (Wang et al., 2007). If the blood is not collected for further processing, it has to be treated as hazardous waste, so the industry is not simply wasting this opportunity, but paying for treatment and neutralisation. Some of the blood and blood proteins are used by the meat industry as a food ingredient as natural colourant, emulsifier, fat substitute, or texture modifying agent. Only about $30 \%$ of the blood from slaughterhouses is used by the food industry worldwide (Ofori and Hsieh, 2012). The blood reduces the amount of cooking loss released during heat treatment by binding water and fat, also forming a kind of matrix that can bind nutrients and flavourings (Chen and Lin, 2002; Toldrà et al., 2008). Blood, containing all its fractions, can only be added into food products in limited quantities. The characteristic smell, colour, and metallic taste of blood is given by the heme part (Duarte et al., 1999). Haemoglobin in the blood could be suitable for preventing the development of iron deficiency due to its higher bioavailability ratio (Liu et al., 1996). However, without compromising the organoleptic properties of the final product, blood can be added to only about $0.5-2.0 \%$ of the product (Ofori and Hsieh, 2012). According to this, blood must be divided into fractions for further use (even for food industry), or innovation of blood-based food products should be encouraged. Consumer preferences are significantly influenced by the colour of meat and meat products (Claus and Du, 2013). Therefore, it is essential that the colour of the finished products should meet the consumer's acceptance, and if possible and technologically feasible, colourants with natural origin should be used. Application of blood as natural colourant is one of the most popular way of using blood. However, the suitability of a natural colourant in a given product is greatly influenced by the form, quantity, and condition in which that specific colourant is available. The microbiological quality of blood from slaughterhouses must be improved before it is used as a food ingredient (Toldrà et al., 2004, 2008). High hydrostatic pressure treatment (HHP) can be suitable for this. HHP is a gentle food preservation process, during treatments the microorganisms in food are partially or completely inactivated by treating the product at a pressure of 100-800 MPa, proteins in microbes are denatured (covalent bonds are broken down) and cell death occurs (Morales et al., 2008), meanwhile organoleptic properties of the product only slightly change (Campus, 2010). In case of the vegetative pathogens, 2-4 log reduction has been observed in various meat products, resulting increased food safety, microbiological stability, and shelf life (Bajovic et al., 2012). HHP treatment of blood and its use is a less researched topic. 
Toldrà et al. (2004) found that HHP treatment of blood at $400 \mathrm{MPa}$ for 15 min caused significant improvement in microbiological quality and did not adversely affect colour characteristics or protein solubility. However, it is essential to examine what kind of physical and chemical changes may occur in the blood as a result of the pressure treatment and how these changes can subsequently affect the properties of the final product.

\section{MATERIALS AND METHODS}

\subsection{Samples}

Bovine blood was obtained from a cattle herd of a rural farm, breed of Hungarian Simmental, age of 6 years. For comparability and to analyse the effects of the pressure treatment, EDTA (ethylene-diamine-tetra-acetic acid) was used as anticoagulant. The samples were vacuum packed airtightly in polyethylene (Cryovac $\odot$, BB4L) package with an average weight of $50 \mathrm{~g}$.

\subsection{HHP treatments}

High-pressure experiments were performed in a Resato FPU-100-2000 (laboratory scale, Resato International B.V, The Netherlands) high-pressure equipment, that contained a pressurising $(1,600 \mathrm{~mm} \times 2,200 \mathrm{~mm} \times 830 \mathrm{~mm})$ and a control $(1,300 \mathrm{~mm} \times 950 \mathrm{~mm} \times 1,400 \mathrm{~mm})$ unit. The samples were subjected to pressure treatments from $100 \mathrm{MPa}$ to $600 \mathrm{MPa}$ with $100 \mathrm{MPa}$ scale up and 5 min holding time, uniformly. The pressure medium was propylene glycol (Resato PG fluid) in the vessel. The initial temperature of the samples was $1-3{ }^{\circ} \mathrm{C}$ (cooled in icy water), and due to the adiabatic heating, sample temperature increased by approximately $3{ }^{\circ} \mathrm{C} / 100 \mathrm{MPa}$ during the treatments. The pressure profiles in the sample holder during the treatments were logged.

\subsection{Colour measurements}

The colour measurements were performed with a Minolta CR-400 (Minolta Co. Ltd., Osaka, Japan) tristimulus colorimeter, repeated five times. During reflection colour measurement, the three data provided by the instrument are $\mathrm{L}^{*}, \mathrm{a}^{*}$, and $\mathrm{b}^{*}$, which can be used to infer the colour and colour change of the samples. To calculate the total colour difference $\left(\Delta E^{*}\right)$ between untreated and treated samples, average values of $L^{*}, a^{*}$, and $b^{*}$ in the following equation were used:

$$
\Delta E^{*}=\left[\left(\Delta L^{*}\right)^{2}+\left(\Delta a^{*}\right)^{2}+\left(\Delta b^{*}\right)^{2}\right]^{0,5}
$$

where $\Delta L^{*}, \Delta a^{*}$, és $\Delta b^{*}$ are the differences between the values of $L^{*}, a^{*}$, and $b^{*}$ in the untreated and treated samples (Salamon et al., 2016).

\subsection{Dynamic viscosity}

For dynamic viscosity measurements Rheomat 115 (Contraves, Malaysia) rotary viscometer was used based on the modified method of Islam and Azemi (1997). For coaxial cylindrical (concentric) viscometers, the liquid is between the two measuring cylinders. Prior to measurement, all samples were set to the same temperature $\left(5^{\circ} \mathrm{C}\right)$. Measurements were carried out in triplicates. Dynamic viscosity (for non-Newtonian fluids) can be calculated from the reading $(\alpha)$, constant of the measuring system $(z=195.5)$ and the velocity gradient $\left(D=57.20 \mathrm{~s}^{-1}\right)$. 


$$
\begin{gathered}
\text { Shear stress : } \tau=\alpha^{*} z[\mathrm{mPa}] \\
\text { Dynamic viscosity }: \eta=\frac{\tau}{D}[\mathrm{mPa}]
\end{gathered}
$$

\subsection{Thermodynamic measurement (DSC)}

A Micro DSC III (Setaram, France) microcalorimeter was used for thermodynamic analysis of control and pressure-treated samples. The reference sample was distilled water. The samples were measured in the temperature range of $20-95{ }^{\circ} \mathrm{C}$, with a reduced heating rate of $1.5{ }^{\circ} \mathrm{C} \mathrm{min}{ }^{-1}$ by the method of Dàvila et al. (2007). The measured sample volume was $778 \pm 10 \mathrm{mg}$ in each case. The obtained heat flux curves were evaluated with Callisto Processing 1.706 program.

\subsection{Microbiological analysis}

Determination of TVC was performed according to the ISO 4833-1: 2014 (2014) standard of plate counting method by using TGA agar.

\subsection{Statistical analysis}

Statistical analyses were performed using SPSS 20.0 for Windows (Chicago, Illinois, USA). To determine the effect of treatments, one-way analysis of variance (ANOVA) was performed at a significance level of $P<0.05$. Tukey's test was applied to compare the mean values when ANOVA showed significant differences.

\section{RESULTS AND DISCUSSION}

\subsection{Colour measurement}

Due to the high pressure treatments, the $\mathrm{L}^{*}$ colour parameter values decreased significantly $(P<0.05)$, highest level of decrease could be observed particularly in case of 300,400 , and 500 $\mathrm{MPa}$ treatments (Fig. 1). The samples lost from their original brightness and became darker. The $\mathrm{a}^{*}$ red colour component results showed an intense decrease due to $300 \mathrm{MPa}$ and above levels of pressure treatments, changes were significant compared to the control sample $(P<0.05)$. The $b^{*}$ yellow colour parameter also showed a significant change in the colour due to pressure treatments at each level $(P<0.05)$. The colour of the blood is mostly given by the haemoglobin in it, so the colour change after the pressure treatment is presumably related to haemoglobin. Bou et al. (2019) found that chicken haemoglobin remains relatively stable after high hydrostatic pressure treatment, however, methaemoglobin and insoluble forms of heme appear. Heme molecule part and its $\mathrm{Fe}^{2+}$-ion redox chemistry properties are presumably responsible for the colour change.

\subsection{Dynamic viscosity}

Figure 2 illustrates the shear stress values obtained as a function of different shear rates. It can be seen from the flow curves that with increasing levels of pressure treatments, the shear stress values also increased. After $400 \mathrm{MPa}$ treatment, the blood sample remained in liquid state, but particularly in case of the 500 and $600 \mathrm{MPa}$ pressure treatments, there was a significant increase 


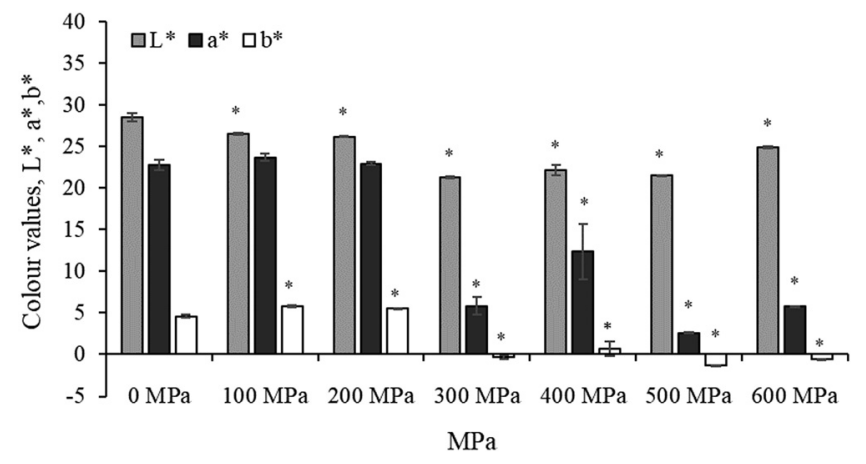

Fig. 1. Changes in colour components of bovine blood after HHP treatment (Asterisk marks the significant changes. The confidence level was 95\%)

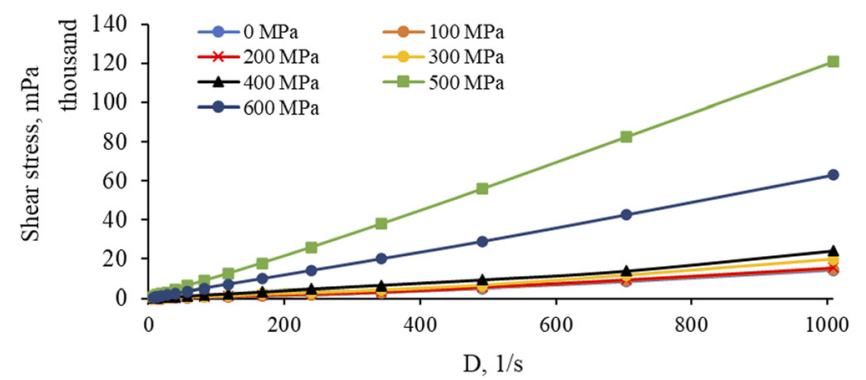

Fig. 2. Changes in shear stress of bovine blood after high pressure treatment

in the viscosity of bovine blood samples $(\eta 400 \mathrm{MPa}=23.95$ Pas, $\eta 500 \mathrm{MPa}=119$ Pas, $\eta 600$ $\mathrm{MPa}=62.54$ Pas, at highest shear rate), the observed differences were even in the order of magnitude of the values. The proteins coagulate due to high hydrostatic pressure treatment, causing to the blood to flow more densely. Presumably the protein denaturation in the samples treated at $600 \mathrm{MPa}$ caused a small amount of plasma release, which resulted in lower values than in case of the $500 \mathrm{MPa}$. The Ostwald-de-Waele model was fitted to the different flow curves so that the parameters of the flow curve could be quantified. The models proved to be adequate in all cases based on the correlation coefficients $\left(r^{2}=0.79-0.99\right)$. The power exponent " $n$ " was less than 1 in each case, which indicates a shear thinning rheological behaviour, therefore, by increasing the deformation rate, the slope of the flow curve decreases, ergo the viscosity also decreases. This probably happens because the damaged (denatured/aggregated) protein fragments are more easily aligned with the direction of shearing during the measurement.

\subsection{Thermodynamic measurement}

The enthalpy peaks in Fig. 3 indicate the aggregation and denaturation of the proteins. According to literature data, the detected peak $\left(68^{\circ} \mathrm{C}-70^{\circ} \mathrm{C}\right)$ probably belongs to albumin, which provides the largest part of blood proteins (Dàvila et al., 2007). On the thermogram, a decrease both in the temperature peak and enthalpy values can be observed compared to the control 


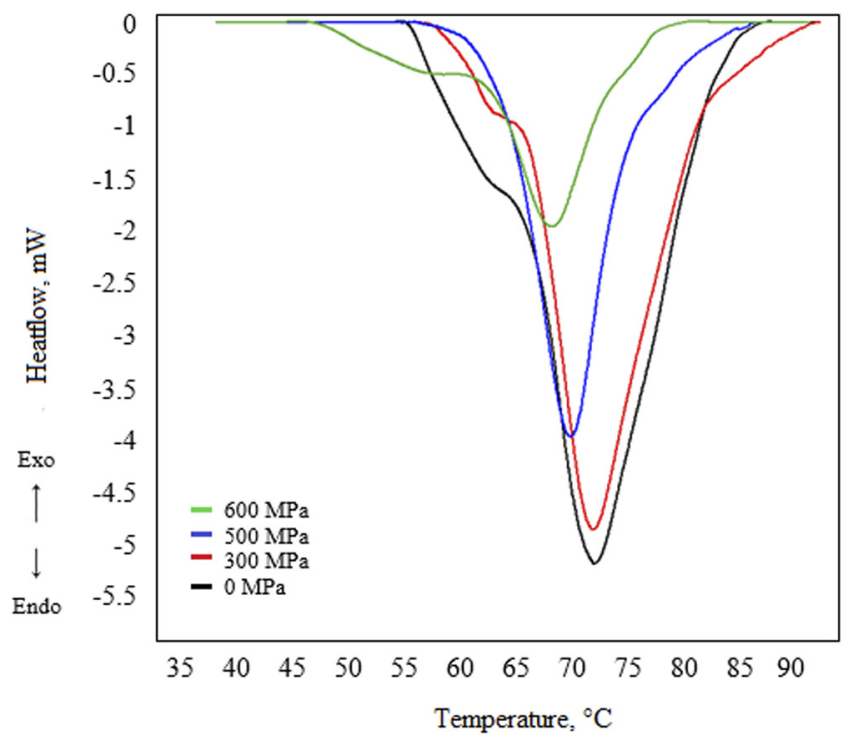

Fig. 3. Changes in thermodynamic characteristics of bovine blood after HHP treatment

sample due to protein denaturation. Particularly at higher levels of pressure, such as 500 and 600 $\mathrm{MPa}$, the enthalpy values decreased with $50 \%$ and $68 \%$, respectively (Csehi et al., 2017). This suggests that the amount of proteins that could be denatured by heat during the thermal analysis was greatly reduced.

\subsection{Microbiological examinations}

The results of the microbiological measurements are shown in Fig. 4. It is clearly visible from the initial values that blood is a great substance for microbial growth, $10^{3} \mathrm{CFU} \mathrm{\textrm {g } ^ { - 1 }}$ was detected

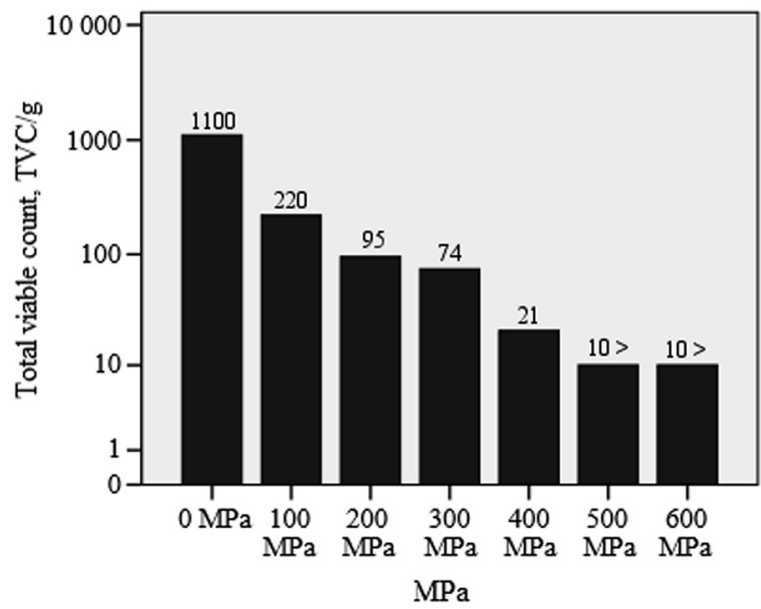

Fig. 4. Microbiological changes of bovine blood after HHP treatment 
already in the control sample even as the samples were only minimally exposed to contamination. From the results it can be concluded that even $100 \mathrm{MPa}$ pressure treatment resulted in an order of magnitude reduction of the number of microbes. As we increased the level of pressure, the TVC number showed a decreasing trend. $400 \mathrm{MPa}$ treatment destroyed nearly all microbes in the blood sample, and above $500 \mathrm{MPa}$ treatment their numbers were below detection limit. Consequently, high pressure treatment can be a good alternative for blood preservation.

\section{CONCLUSIONS}

Based on the above results, it can be established that high pressure treatment of $400 \mathrm{MPa}$ is already effective to reach the sufficient microbiological stability of bovine blood, as it results in a 2 order of magnitude microbial count reduction, possibly providing more stable raw material for further processes from food safety perspective. According to the thermophysical measurements (DSC), the pressure of $400 \mathrm{MPa}$ does not yet cause severe changes in the protein structure, so the blood remains in a liquid state, therefore, it can be used conveniently from a techno-functional point of view.

\section{ACKNOWLEDGEMENTS}

The Project is supported by the European Union and co-financed by the European Social Fund (grant agreement no. EFOP-3.6.3-VEKOP-16-2017-00005).

\section{REFERENCES}

Bajovic, B., Bolumar, T., and Heinz, V. (2012). Quality considerations with high pressure processing of fresh and value added meat products. Meat Science, 92: 280-289.

Bou, R., Llauger, M., Joosse, R., and García-Regueiro, J.A. (2019). Effect of high hydrostatic pressure on the oxidation of washed muscle with added chicken hemoglobin. Food Chemistry, 292: 227-236.

Campus, M. (2010). High pressure processing of meat, meat products and seafood. Food Engineering Reviews, 2: 256-273.

Csehi, B., Szerdahelyi, E., Németh, C., Jónás, G., Salamon, B., Pásztor-Huszár, K., and Friedrich, L.(2017). Increasing the microbiological stability of blood (as food industrial by-product) by high hydrostatic pressure treatment, Book of Abstracts.539. In: The 26th International Conference on High Pressure Science \& Technology (AIRAPT 26), Beijing, Kína (2017).

Chen, M.-J. and Lin, C.-W. (2002). Factors affecting the water-holding capacity of fibrinogen/plasma protein gels optimized by response surface methodology. Journal of Food Science, 67: 2579-2582.

Claus, J.R. and Du, C. (2013). Nitrite-embedded packaging film effects on fresh and frozen beef colour development and stability as influenced by meat age and muscle type. Meat Science, 95:526-535.

Dàvila, E., Parés, D., Cuvelier, G., and Relkin, P. (2007). Heat-induced gelation of porcine blood plasma proteins as affected by $\mathrm{pH}$. Meat Science, 76: 216-225. 
Duarte, R.T., Carvalho Simões, M.C., and Sgarbieri, V.C. (1999). Bovine blood components: Fractionation, composition, and nutritive value. Journal of Agricultural and Food Chemistry, 47:231-236.

Eurostat: Slaughtering in slaughterhouses statistics, Available at https://appsso.eurostat.ec.europa.eu/nui/ show.do?dataset $=$ apro_mt_pwgtm\&lang $=$ en (last accessed 6 June 2020).

In, M.-J., Jeong Chae, H., and Oh, N.-S. (2002). Process development for heme-enriched peptide by enzymatic hydrolysis of hemoglobin. Bioresource Technology, 84: 63-68.

Islam, M.N. and Azemi, B.M.N.M. (1997). Rheological properties of calcium treated hydroxypropyl rice starches. Starch/Stärke, 49: 136-141.

Liu, X.Q., Yonekura, M., Tsutsumi, M., and Sano, Y. (1996). Physicochemical properties of aggregates of globin hydrolysates. Journal of Agricultural and Food Chemistry, 44: 2957-2961.

Lynch, S.A., Mullen, A.M., O'Neill, E.E., and García, C.Á. (2017). Harnessing the potential of blood proteins as functional ingredients: a review of the state of the art in blood processing: blood processing and food applications. Comprehensive Reviews in Food Science and Food Safety, 16: 330-344.

Morales, P., Calzada, J., Ávila, M., and Nuñez, M. (2008). Inactivation of Escherichia coli O157:H7 in ground beef by single-cycle and multiple-cycle high-pressure treatments. Journal of Food Protection, 71: 811-815.

Ofori, J.A. and Hsieh, Y.-H.P. (2011). Blood-derived products for human consumption. Revelation and Science, 1: 14-21.

Ofori, J.A. and Hsieh, Y.-H.P. (2012). The use of blood and derived products as food additives. In: ElSamragy, Y. (Ed.), Food additive, Vol. 13. Intech Open, pp. 229-256.

Salamon, B., Tóth, A., Palotás, P., Südi, G., Csehi, B., Németh, Cs., and Friedrich, L. (2016). Effect of high hydrostatic pressure (HHP) processing on organoleptic properties and shelf life of fish salad with mayonnaise. Acta Alimentaria, 45: 558-564.

Sorapukdee, S. and Narunatsopanon, S. (2017). Comparative study on compositions and functional properties of porcine, chicken and duck blood. Korean Journal for Food Science of Animal Resources, 37: 228-241.

Toldrà, M., Dàvila, E., Saguer, E., Fort, N., Salvador, P., Parés, D., and Carretero, C. (2008). Functional and quality characteristics of the red blood cell fraction from biopreserved porcine blood as influenced by high pressure processing. Meat Science, 80: 380-388.

Toldrà, M., Elias, A., Parés, D., Saguer, E., and Carretero, C. (2004). Functional properties of a spray-dried porcine red blood cell fraction treated by high hydrostatic pressure. Food Chemistry, 88: 461-468.

USDA United States Department of Agriculture, National Agricultural Statistics Service, Quick Stats. Available at https://quickstats.nass.usda.gov/ (last accessed 18 Aug 2020).

Wang, J.Z., Zhang, M., Ren, F.Z., Han, B.Z., Wang, L., Chen, S.W., and Humera, A. (2007). Changes of chemical and nutrient composition of porcine blood during fermentation by Aspergillus oryzae. World Journal of Microbiology and Biotechnology, 23: 1393-1399.

Open Access. This is an open-access article distributed under the terms of the Creative Commons Attribution 4.0 International License (https://creativecommons.org/licenses/by/4.0/), which permits unrestricted use, distribution, and reproduction in any medium, provided the original author and source are credited, a link to the CC License is provided, and changes - if any - are indicated. (SID_1) 